\title{
Governance, Peace and Human Rights Violations in Africa: Addressing the Application of the Right to Self-Determination in Post-Independence Africa
}

\author{
Mtendeweka Mhango* \\ Oliver Schreiner School of Law, University of the Witwatersrand, Johannesburg, South Africa
}

\begin{abstract}
Recent claims of self-determination in post-independence Africa have put pressure on African regional judicial bodies to define the scope of this right. This article examines governance, peace and human rights violation issues in the context of the application of the right to self-determination in post-independence Africa. It scrutinizes the ruling by the African Commission in Katangese Peoples Congress v. Zaire, and argues that this ruling exhibits the African Commission's encouraging view of self-determination under the African Charter, and the likely recognition of a right to an autonomy regime in post-independence Africa. The article maintains that many of the legal issues in Katanga will likely be raised again, either before the African Commission or the African Court, due to recent and increased claims of self-determination by groups within African states. It examines whether the recognition of a right to autonomy regime could have positive impact on good governance, peace and development in Africa.
\end{abstract}

\section{Keywords}

Self-determination; autonomy regime; independence; secession; ethnic group; borders; conflict; Katanga

\section{Introduction}

One of the first problems that confronted the newly independent states of Africa was how to deal with the implementation of claims of self-determination in the post independence era. ${ }^{1}$ These problems emerged in 1960s in the context of border disputes between Morocco and Algeria; Ghana and Upper Volta (now Burkina Faso); Somalia and Kenya; and Somalia and Ethiopia. ${ }^{2}$ The way these

\footnotetext{
*) E-mail: mhangomt@msu.edu. The author is Associate Professor and Deputy Head at the Oliver Schreiner School of Law, University of the Witwatersrand, Johannesburg, South Africa.

This article was presented at the International Conference on the Future of International Criminal law in Africa in 2010 at the University of the Witwatersrand School Of Law. I would like to thank the anonymous reviewers who commented on an earlier draft of this paper.

1) See, S. Touval, 'The Organization of African Unity and African Borders' (1967) 21(1) International Organizations 102; M. Haile, 'Legality of Secession: The Case of Eritrea' (1994) 8 Emory International Law Review 479; and S. Ratner, 'Drawing A Better Line: Uti Possidetis and the Borders of News State' (1996) 90 American Journal of International Law 590.
}

2) Touval, supra note 1, p. 103. 
disputes were handled and resolved (or not resolved) has informed the jurisprudence of the African Commission on Human and Peoples' Rights ("African Commission") and the scope of the right to self-determination in Africa. The effort to solve these problems began in 1963, when leaders of the new independent African states met in Ethiopia to discuss pressing issues affecting Africa. Among the issues that were discussed were the border disputes mentioned above. Of particular interest to us are the disputes between Somalia and Ethiopia and Somalia and Kenya, which were considerably underpinned by Somalia's claims of the right to self-determination. According to commentators, the dispute involving Somalia originated from an assertion of ethnic nationalism by Somalis, in which the Somalis sought to establish a Somali nation-state which would incorporate all Somali people within its borders including those Somalis residing in the Ethiopian and Kenyan territories. ${ }^{3}$ Essentially, Somalia invoked the right to self-determination on behalf of Somalis residing in Kenya and Ethiopia. If Somalia's claim had been successful, it would have had the effect of redrawing the borders of Somalia, Kenya, Ethiopia and possibly other countries in Africa. Unfortunately, the Somalia's claim was not successful.

In resolving these border and self-determination claims, African states were divided. They were those in the minority, such as Ghana, Morocco and Somalia, which favored a more radical means of resolving border and self-determination claims in post-independence Africa, which would involve the redrawing of borders. For example, Dr. Kwame Nkrumah of Ghana maintained that the only way to solve the frontier problem was through African unity at a continental scale. ${ }^{4}$ According to Nkrumah, border disputes had only been smothered and not settled, and he warned of added disputes to come which, according to him, could only be solved by the union of all African states. Somalia's position was not identical to Ghana's, but it opposed a prohibition on claims of self-determination within independent states and the redrawing of borders in post-independence Africa. Somalia's preferred position was that claims of self-determination should not be restricted in post-independence Africa, but should be permitted for groups within existing states. These were progressive notions which were rejected in favor of the majority position that emerged in 1963 and subsequently in 1964 with the adoption of the Cairo Resolution of $1964 .^{5}$

Historical accounts confirm that the majority of the African states disagreed with the views of Ghana and Somalia. They felt that existing borders should be

\footnotetext{
3) Touval, supra note 1, p. 111; A. Costagno, 'The Somali-Kenya Controversy' (1964) 2 Journal of Modern African Studies 165; I. Lewis, 'Pan Africanism, and Pan Somalism' (1963) 1 Journal of Modern African Studies 147; and S. Touval, Somalia Nationalism (Havard University Press, New Haven, CT, 1970).

4) Touval, supra note 1, p. 104. For further discussion about Nkrumah's views on African unity See, K. Nkrumah, Africa Must Unite (Panaf, London 1998).

5) Resolution AHG/Res 16(I) (Border Disputes Among African States), adopted on 21 July 1964 by the First Ordinary Session of the Assembly of Heads of State and Government.
} 
maintained to preserve peace and stability. ${ }^{6}$ Representing the majority view was President Modiba Keita of Mali who put it plainly when he said:

\footnotetext{
We must take Africa as it is, and we must renounce any territorial claims, if we do not wish to introduce black imperialism in Africa. African unity demands of each one of us complete respect for the legacy that we have received from the colonial system, that is to say, maintenance of the present frontiers of our respective states ${ }^{7}$
}

Kenya and Ethiopia supported Mali's position. They maintained that the principle of self-determination should apply only to colonial territories and not to parts of sovereign independent states of Africa. ${ }^{8}$ Additionally, Kenya maintained that the principle of self-determination should not apply to people within existing states, and cautioned that employing the right to self-determination to redraw borders along ethnic lines would affect many African states. ${ }^{9}$ The majority view led to the adoption of the Cairo Resolution of 1964 in which the states pledged to respect colonial borders. ${ }^{10}$ Professor Saadia Touval has observed that the Cairo Resolution is silent on the question of self-determination, and yet the practice of African states is very clear that attempts to re-draw the borders by groups claiming the right to self-determination should be rejected. ${ }^{11}$ Touval argues that the omission of any reference in the Cairo Resolution to problems involving claims of self-determination by groups within states creates uncertainty in the law. ${ }^{12}$ However uncertain, the current legal position is a cause of concern to many and may be the source of many problems facing Africa today.

The majority view that prevailed in the early 1960s is not progressive and has not sufficiently transformed in light of the changing socio-political realities in Africa, but has continued to dominate the thinking and jurisprudence around questions involving the right to self-determination. This is evident in the 1992 case of Katangese Peoples Congress v. Zaire ${ }^{13}$ (hereinafter Katanga). Katanga is the African Commission's landmark ruling on the inalienable right to self-determination under the African Charter on Human and Peoples' Rights ("African Charter"), which entered into force in 1986. Specifically, the African Commission had to determine whether the region of Katanga in Zaire (formerly Congo, now the

6) Touval, supra note 1, p. 104.

7) Ibid.

8) Ibid, p. 111. See also Haile, supra note 1, p. 509.

9) Touval, supra note 1, p. 115.

10) Cairo Resolution, supra note 5.

11) Touval, supra note 1, p. 125.

12) Ibid.

13) Katangese Peoples' Congress v. Zaire, Comm. No. $75 / 92$ (African Commission for Human and Peoples' Rights 1995) in Eighth Annual Activity Report of the African Commission on Human and Peoples' Rights (1994-1995), ACHPR/RPT/8th, Annex VI (1995). 
Democratic Republic of Congo or DRC) could achieve the right to self-determination in the form of secession or independence from the DRC. The African Commission ruled that the right to self-determination under the African Charter may only be achieved in a manner that is consistent with the sovereignty and territorial integrity of the DRC. The decision in Katanga continues to bear great normative value because it is the African Commission's first decision directly addressing the possible right to autonomy in post-independence Africa. Since Katanga, many ethnic groups in African countries, including Zambia, Angola, Malawi and Ethiopia, continue to vigorously assert their right to self-rule or to a greater and meaningful participation within their states. These developments have raised a critical question of whether these groups are seeking independence or simply autonomy within their existing states. While no group has out-rightly claimed the right to autonomy as a breed of self-determination on the basis of Katanga, the legacy in Katanga will greatly inform the potential realization of this right in the years to come, and perhaps contribute towards peace and good governance in Africa.

The African Charter is currently the only regional human rights instrument that permits the right to self-determination to be the subject matter of communications submitted to the African Commission by entities other than states. The right to self-determination is by far one of the most important and perhaps contentious rights enshrined in the African Charter because it is the vehicle through which many African states achieved independence from colonialism. Recent claims of self-determination in post-independence Africa have put pressure on the African Commission to define the scope of this right on the continent, and will likely exert similar pressures on the newly established African Court on Human and People's Rights, which complements the protective mandate of the African Commission.

This article examines governance, peace and human rights violation issues in the context of the application of the right to self-determination in post-independence Africa. The article examines the ruling in Katanga, and argues that Katanga exhibits the African Commission's progressive view on self-determination under the African Charter, and the probable recognition of a right to an autonomy regime. ${ }^{14}$ This hypothesis is supported by the African Commission's decision with regard to the conflict between Senegal and the separatist movement in the region of Casamance. In its decision involving Senegal, the African Commission rejected the claims of independence for the region of Casamance in favor of a certain measure of autonomy in the administration of public affairs for the region of Casamance. It recommended that Senegal appoint in Casamance officials native to the region

14) See, Report on Mission of Good Offices to Senegal of the African Commission on Human and Peoples' Rights (1-7 June 1996) in Tenth Annual Activity Report of the African Commission on Human and Peoples' Rights (1996-1997), ACHPR/RPT/10th, Annex VIII (1997). 
to enhance their participation in government and allow them to realize their right of self-determination within Senegal. ${ }^{15}$

On the other hand, while its decision in Katanga should be commended for demonstrating that self-determination is justiciable under the African Charter, the African Commission should be criticized for leaving several unanswered questions. What is meant by "other forms of self-determination that are fully cognizant of recognized principles of sovereignty and territorial integrity"? Would the African Commission have reached a different outcome had the complainant in Katanga applied for an autonomy regime that did not require Katanga's independence from the DRC? In other words, would the outcome have been different had the complainant sought to achieve self-determination within the DRC? Are various ethnic, religious and other minority groups within Africa states similarly entitled to self-determination?

The article addresses these questions and the long-term significance of Katanga in post-independence Africa, more especially in relation to governance, peace and human rights violations in Africa. The article examines whether the recognition of the right to autonomy could have a positive impact on good governance, sustainable peace and development in Africa's troubled territories. The article argues that while international law does not prohibit self-determination in the form of secession, ethnic groups seeking self rule or meaningful participation in African governments should be encouraged to seek achievement of the right to self-determination within their existing states.

\section{The History and Scope of the Right to Self-Determination}

The question of whether the right to self-determination is capable of judicial enforcement elicited heated debate at the United Nations during the drafting of the International Bill of Human Rights. The outcome of the controversy was the bifurcation of the Universal Declaration of Human Rights into the International Covenant on Civil and Political Rights ("ICCPR") and the International Covenant on Economic, Social and Cultural Rights ("ICESCR"). The contention that self-determination is a political principle and not a right formed the basis for opposition from western countries to its inclusion in the two international instruments. Western countries had argued that self-determination is a collective right and mismatched with a human rights convention based on the protection of the individual. As a result, this collective right could not be enforced by the Human Rights Committee (the Committee) in the same manner as individual rights. Other criticisms branched from the economic aspects of the right to self-determination. ${ }^{16}$ Nevertheless, Western countries took part in the drafting

\footnotetext{
15) Ibid.

16) See, e.g., C. Iorns, 'Indigenous Peoples and Self Determination: Challenging State Sovereignty' (1992) 24 Case Western Reserve Journal of International Law 281; and A. Farmer, 'Towards a Meaningful Rebirth
} 
of the text of Article 1 of the ICCPR and ICESCR. Some commentators have observed that the inclusion of the right to self-determination in both the ICCPR and ICESCR indicates that self-determination is both a civil and political right, and an economic, social and cultural right. ${ }^{17}$ Furthermore, its inclusion in Part I of each Covenant underlines its importance.

Another hotly debated issue was whether ethnic or religious minorities should be accorded the right to self-determination. The Soviet proposal that the protection of minorities be dealt with in the context of the right to self-determination under Article 1 was defeated on the basis that the rights of minorities are enshrined in a separate provision of the ICCPR, namely Article 27 . While the ICCPR has a provision for judicial enforcement through individual petitions pursuant to the First Optional Protocol of the ICCPR, in Lubicon Lake Band v. Canada ${ }^{18}$ the Committee ruled that an individual could not bring a case for violation of Article 1 because the latter enshrines a collective right and not an individual right. In Lubicon Lake Band, the Committee held that the First Optional Protocol of the ICCPR only provides a procedure for petitions concerning violations of individual rights set out in Part II of the ICCPR, namely Articles 6 to 27. Therefore, groups that attempt to assert their right of self-determination will have to depend on inter-state communication procedures and state reports, the former of which have yet to be used, in order to clarify the Committee's interpretation of this right under the ICCPR.

Unlike the ICCPR, the African Charter extends similar enforcement mechanism to all categories of rights. It allows for communications from states under Article 47 as well as individuals under Article 55 alleging violations of any rights, and the standing requirements for bringing communications before the African Commission are liberally construed. For example, unlike the First Optional Protocol of the ICCPR, where the individual complaints procedures are severed from the ICCPR itself, individuals as well as NGOs with observer status can bring communications against a state under the African Charter.

Because of this, the African Commission has recognized self-determination as a justiciable right under the African Charter. In both the Katanga and Casamance communications, ${ }^{19}$ the African Commission accepted complaints by ethnic groups alleging violations of the right to self-determination. In both instances, the communications were brought by non-state parties, both requesting self-

of Economic Self-Determination: Human Rights Realization in Resource-Rich Countries' (2006) 39 New York University Journal of International Law \& Politics 417.

17) See, A. Cassese, The Self-Determination of Peoples, in The International Bill of Rights: the Covenant on Civil and Political Rights 93, Louis Henkin, ed. (Columbia University Press, New York, NY, 1981); and E. Kolodner, 'Population Transfer: The Effects of Settler Infusion Policies on A Host Population's Right to Self-Determination' (1994) 27 New York University Journal of International Law \& Politics 159.

18) Chief Ominyak and Lubicon Lake Band v. Canada, Comm. No. 167/1984 (United Nations Human Rights Council 1990), U.N. Doc. Supp. No. 40 (A/45/40) at 1 (1990).

19) Report on Mission of Good Offices to Senegal of the African Commission on Human and Peoples' Rights, supra n. 3. 
determination in the form of secession or independence. Overall, these communications demonstrate that self-determination under the African Charter is justiciable like all other rights therein. Some human rights scholars writing in the early history of the African Charter questioned whether peoples' rights in the African Charter were appropriate for consideration by the African Commission. ${ }^{20}$ They argued that peoples' rights in the African Charter were clearly lofty ideals and laudable aspirations rather than enforceable rights and the African Commission's function was simply promotional. As a result, peoples' rights under the African Charter should not be the subject of communication before the African Commission. ${ }^{21}$ The Katanga and Casamance communications reject these earlier understandings of the African Charter and clarify that people's rights are subject of communications and direct enforcement.

\section{The Conflict in the Katanga Region}

After the DRC was granted independence from Belgium in June 1960, Katanga became an autonomous province. On 11 July 1960, Katanga broke away from the new DRC government of Prime Minister Patrice Lumumba, declaring independence under Moise Tshombe, the leader of the local political party. Despite this development, the new Katangese government did not enjoy international support. After Prime Minister Lumumba was assassinated by forces from Katanga in 1961, the UN Security Council adopted resolution 161, ${ }^{22}$ which authorized UN intervention in the DRC. After Lumumba's death, Tshombe agreed to reunite with the DRC. However, some elements within the region of Katanga preferred that Katanga should be independent from the DRC. ${ }^{23}$

For example, in 1992, Gerard Moke, the leader of the Katangese Peoples Congress (KPC), the only political party representing the people of Katanga at the time, brought a communication before the African Commission. The complainant presented the history of colonial division of the DRC's political boundaries and the effect of these on the region of Katanga. It included emphasis on the different treatment of the Katanga region by the colonial powers in the 19th century. Pursuant to this, the complainant prayed that the African Commission grant

\footnotetext{
20) U. Umozurike, 'The African Charter on Human and Peoples' rights: Suggestions for More Effectiveness' (2007) 13 Annual Survey of International and Comparative Law 179, 181; and E. Bondzie-Simpson, 'A Critique of the African Charter on Human and Peoples' Rights' (1988) 31 Howard Law Journal 643.

21) Bondzie-Simpson, supra note 20, p. 657.

22) UN Security Council, Security Council resolution 161 (1961), 21 February 1961, S/RES/161 (1961), available online at http://daccess-dds-ny.un.org/doc/RESOLUTION/GEN/NR0/171/68/IMG/ NR017168.pdf?OpenElement (accessed 1 November 2011).

23) For a discussion of the history of the conflict in the DRC, See T. Kanza, The Rise and Fall of Patrice Lumumba: Conflict in the Congo (Hall, Boston, MA, 1979); W. Okumu, Lumumba's Congo: Roots of Conflict (Obolensky, New York, NY, 1963); and A. Merriam, Congo: Background of Conflict (Northwest University Press, Evanston, IL, 1961).
} 
the following relief: (1) recognize the KPC as a liberation movement entitled to support to achieve independence for Katanga; (2) recognize the independence of Katanga; and (3) help secure the DRC's withdrawal from the Katanga region.

The complainant brought this complaint under Article 20(1) of the African Charter, which protects the inalienable right to self-determination..$^{24}$ The request for some form of assistance for the people of Katanga was presumably brought pursuant to Article 20(3) of the African Charter, which provides for the right to political, economic or cultural assistance from state parties to the African Charter in a liberation struggle, and hence the prayer by the complainant to have the KPC recognized as a liberation movement under the African Charter.

The African Commission found that there were no remedies available under national law that would guarantee the independence of Katanga from the DRC. Furthermore, the African Commission could not identify any specific allegations of violations of the African Charter in the complaint. Because neither the African Commission nor the DRC could justify dismissal on grounds that the complainant failed to exhaust local remedies, since no such remedies were available, the complaint was found admissible.

\section{The Right to Participate in Government and Public Affairs}

One of the reasons that triggers claims for self rule or independence by ethnic groups in Africa is their marginalization or exclusion from meaningful participation in government. When groups feel marginalized or excluded from the affairs of the state, often this generates claims for self rule. The African Commission in Katanga has emphasized that all peoples have the right to self-determination. It explained that this right may be "exercised in any of the following ways: independence, self-government, local government, federalism, confederalism, unitarism, or any other form of relations that accords with the wishes of the people but fully cognizant of other recognized principles such as sovereignty and territorial integrity." 25 The African Commission also suggested that where a people is able to establish a breach of the right to participate in government coupled with other verifiable human rights violations, self-determination in the form of secession may be possible under the African Charter. Even though the African Commission correctly recognized the close relationship between the right to self-determination and the right to participate in government, as guaranteed in Articles 20 and 13, respectively, it was also mindful to emphasize its commitment to, and duty to uphold, the fundamental character of the principles of territorial integrity and sovereignty.

\footnotetext{
24) African Charter on Human and Peoples' Rights (ACHPR), Oct. 21, 1986, 1520 U.N.T.S. 217, Art. 20(1).

25) Katanga, supra note 13, at para. 4.
} 
The African Commission recognized that Katanga involved not the selfdetermination of all peoples of the DRC, but rather only the people of Katanga, a province within the DRC. Yet because there was no evidence as to whether Katanga consisted of more than one ethnic group, the African Commission did not have to define the term peoples in the context of self-determination. ${ }^{26}$ As a result, it intentionally neglected to discuss the legal effect of recognizing the inhabitants of Katanga as peoples. Instead, the African Commission focused its discussion of the right of peoples to participate in government.

It is in this respect that Professor Li-ann Thio has criticized the African Commission's decision as politically motivated and lacking any precise legal reasoning. ${ }^{27}$ According to the African Commission, granting the prayer of the people of Katanga would contravene the principle of uti possidetis, which the former Organization of African Unity (OAU), now African Union, had pledged to uphold in the Cairo Resolution. ${ }^{28}$ Ultimately, the African Commission avoided discussing the more pertinent question of whether the term peoples in the African Charter includes ethnic groups by focusing on the question of whether the right of the inhabitants of the Katanga region to participate in government was breached by the DRC.

\section{Understanding the Term 'Peoples' Under the African Charter}

For years, the debate on the criteria of the right to self-determination has centered on the definition of peoples. ${ }^{29}$ Since the African Charter purposely did not define the term, it could be argued that this task was left to the African Commission, and other treaty bodies to interpret. It is, therefore, important for the African Commission to clarify this term in future communications.

\footnotetext{
26) Likewise, the Commission did not define this term in its recent decision in The Social and Economic Rights Action Center for Economic and Social Rights v. Nigeria, African Commission on Human and Peoples' Rights, Comm. No. 155/96 (African Commission for Human and Peoples' Rights, 2001), but found that the right of the Ogoni people to dispose of their wealth and natural resources under Article 21 of the ACHPR had been violated. By inference, however, the Commission viewed both the inhabitants of Katanga and Ogoni as peoples.

27) L. Thio, 'Battling Balkanization: Regional Approaches Toward Minority Protection Beyond Europe' (2002) 43 Harvard International Law Journal 466.

28) The principle of uti possedetis states that newly decolonized states should inherit colonial administrative borders held at the time of independence.

29) See, H. Espiell, The Right to Self-Determination: Implementation of United Nations Resolutions 9 U.N. Doc. E/CN.4/Sub.2/405/Rev.1 Para. 56 (1980) (in this study, Espiell clearly disqualified minorities, but stated that the law could develop to give them the right to self-determination), See also Human Rights Committee's General Comment 23 on art. 27 (50th Sess. 1994), reprinted in Compilation of General Comments and General Recommendations adopted by Human Rights Treaty Bodies, U.N. Doc. HRI.GEN/1/Rev. 3 (1997), P 3.1, at 39 (commenting that the right to self-determination belongs to peoples and not minorities); and A. Cassese, Self-Determination-A Legal Appraisal (Cambridge University Press, New York, NY, 1995).
} 
In Africa, there appear to be two schools of thought on the term peoples. The first is represented by African Commissioner Isaac Nguema, who holds that peoples, as understood by the framers of the African Charter, applies to the entire population of the country. For example, those that had formerly been colonized by European states, such as Nigerians, without making a formal distinction between the Yoruba or Kanuri. ${ }^{30}$ The African states have individually (under the auspices of the former OAU) taken the position that self-determination does not apply outside the colonial context because post-colonial application would undermine African unity. This school of thought is not preferred because it denies ethnic groups in Africa, many of whom feel marginalized and dominated by another group within their state, the right to meaningfully participate in government. ${ }^{31}$

The second school of thought is represented by African Commissioner Oji Umozurike, who holds that peoples denotes groups of people that have an identifiable interest, such as tribes or fishermen. For instance, Article 19 provides that no people may dominate another people, but does not stipulate that peoples mean all the people of the country. ${ }^{32}$ Instead, the term could refer to members of ethnic groups or even other social groups within a state. This school of thought is the most preferred because it presents no considerable hindrance to the enjoyment of the right to self-determination.

The African Commission is well aware of these competing legal positions but failed to issue a definitive ruling to clarify the law in Katanga. ${ }^{33}$ For all practical purposes, Katanga seems to uphold the conservative position represented by African Commissioner Nguema, which continues to view the right to self-determination within the colonial lens. This view is also consistent with the majority position that prevailed in the early 1960s. If the construction of the term peoples in the African Charter is restricted to all persons within a state, then the people of Katanga and others may not be able to enjoy certain rights under the Africa Charter such as those enshrined in Articles 19 to 24.

It is doubtful, however, that the framers of the African Charter intended to create a self-liquidating right of self-determination only for those peoples who were formerly colonized. ${ }^{34}$ They must have envisaged that Africa would eventually

\footnotetext{
30) ACHPR, Examination of State Reports (Libya-Rwanda-Tunisia) in General Discussions (9th Session, March 1991), available online at http://0-www1.umn.edu.innopac.up.ac.za:80/humanrts/achpr/sess9toc.htm. At its 16th Session in October 1994, the ACHPR authorized the Danish Center for Human Rights to publish, in its name, the transcripts of the examinations of state reports which have taken place thus far.

31) D. Bouvean, 'A Case Study of Sudan and the Organization of African Unity' (1998) 41 Howard Law Journal 442 (criticizing the current rigid interpretation of the right to self-determination in Africa).

32) Ibid.

33) Katanga, supra note 13. See also, The Social and Economic Rights Action Center for Economic and Social Rights v. Nigeria, African Commission on Human and Peoples' Rights, Comm. No. 155/96 (African Commission for Human and Peoples' Rights, 2001).

34) But see Cassese, supra note 15, p. 72-73 (noting that the right declared in the 1960 UN Declaration on Granting Independence to Colonial Countries and Peoples concerns only external self-determination
} 
be free from colonial rule but still burdened by other socio-economic and political problems that necessitate claims of self-determination. It is important for the African Commission to liberally construe the right to self-determination as directly applicable to ethnic groups and others as peoples entitled to this right. This interpretation is progressive and consistent with the African Charter because it effectively recognizes the diverse ethnic composition of Africa. In practice, some African states like Uganda, Ethiopia and Nigeria have acknowledged ethnic or religious identities and have accommodated them within their political and governance systems. ${ }^{35}$

Assuming African Commissioner Nguema is correct to suggest that the term peoples in the African Charter only refers to those formerly colonized, then it could equally be accurate to suggest that Article 20 and others similar to it were probably nullified when the last colonized state in Africa became independent in 1994. Yet the preferred interpretation is more in tune with African Commissioner Umozurike's view that the African Charter was created to prevent human rights atrocities occurring both before and after its adoption. Accordingly, I submit that the African Charter should be interpreted in light of the changing circumstances on the continent where self-determination is viewed as an ongoing process relevant to assist resolve current conflicts in Africa. Most African states have been independent for more than 20 years, yet there are more conflicts than stable independent states on the continent. It is submitted that Commissioner Umozurike's interpretation of the African Charter should be welcomed because it allows for African states to experiment with the application of the right to self-determination.

\section{The Impact of the OAU on the Future Application of the Right to Self-Determination}

African Commissioner Nguema's position that self-determination does not apply outside the colonial context is consistent with the position adopted in the Cairo Resolution. The Cairo Resolution solemnly declared that all Member States pledge themselves to respect the borders existing on their achievement of national independence ${ }^{36}$ in a manner that is in harmony with the principles of sovereignty and territorial integrity in the OAU Charter. The Cairo Resolution is relevant to the post-colonial application of self-determination because it informed the basis on which Katanga was decided. The African Commission

and expires once it has been exercised, either by the choice to form a new state or to associate or integrate with an existing state).

35) See, S. Slimane, 'Recognizing Minority Rights Groups', African Briefing (May 2003), Minority Rights Groups International, available online at http://www.minoritytights.org (accessed 21 January 2012).

36) Resolution on Border Dispute Among African States, AHG/Res. 16(I) (1964). See also Touval, supra note 1, p. 102-127 (discussing historical events leading to the adoption of the Cairo Resolution). 
relied on the Cairo Resolution in setting the standard by which the right to selfdetermination would be implemented in post-independence Africa. The problem is that the former OAU failed to incorporate provisions that would ensure the survival of other forms of self-determination given the changing circumstance in post-independence Africa.

It is important to note that the Cairo Resolution was motivated by boundary conflicts in early 1963 between Somalia, Ethiopia and Kenya. Somalia had attempted to exercise the right to self-determination for Somalis living in Ethiopia and Kenya. This claim was rejected by the OAU in favor of Ethiopia's contention that a claim for self-determination in the post-colonial context was unacceptable. ${ }^{37}$ The OAU favored Ethiopia's position because of fear that African governments would not ratify the African Charter absent such a prohibition.

Since the Cairo Resolution, which was affirmed by the decisions of the International Court of Justice in Burkina Faso v. Mali ${ }^{38}$ and Katanga, ${ }^{39}$ claims of selfdetermination in the form of secession are prohibited under the African Charter in favor of claims that can be achieved without altering existing state boundaries. This, however, raises the question of whether the Cairo Resolution, and the subsequent decisions affirming it, amount to an implicit approval of claims of autonomy regime given they can only be achieved in harmony with Article 3(3) of the former OAU Charter. In other words, since the right to self-determination is recognized as a justiciable right under the African Charter, does the prohibition of secessionist claims such as the one in Katanga suggest the approval of other claims of self-determination, which are not hostile to sovereignty and territorial integrity of states? If so, did the decision in Katanga approve a right to autonomy regime under the African Charter?

\section{The Right to Self-Determination in Canada: The Case of Quebec}

One of the most important authorities on the right to self-determination is the advisory opinion in Reference re Secession of Quebec (Secession of Quebec)..$^{40} \mathrm{In}$ Secession of Quebec the Canadian Supreme Court was presented with a challenge that raised legal questions similar to those in Katanga. Among the questions before the Supreme Court were the following: Does international law give the National Assembly, legislature or government of Quebec the right to effect the secession of Quebec from Canada unilaterally? In this regard, is there a right of self-determination under international law that would give the National Assembly, legislature or government of Quebec the right to effect the secession of

37) Touval, supra note 1, p. 112-122.

38) Frontier Dispute (Burk. Faso v. Mali), 1986 I.C.J. 554 (Dec. 22).

39) Katanga, supra note 13.

40) Reference re Secession of Quebec, [1998] 2 S.C.R. 217 (Can.). 
Quebec from Canada unilaterally? ${ }^{31}$ The Canadian decision is relevant to the analysis of Katanga because both the factual setting from which the case arose, and the legal conclusion reached by the Canadian Supreme Court are similar. For instance, the complainants in both cases sought to achieve the right to self-determination in the form of secession or independence, and each alleged a breach of their right to participate in government. In both decisions the prayer for secession or independence was rejected, and no breach of the right to participate in government was found.

Similar to the African Commission, the Supreme Court in Secession of Quebec recognized the relationship between the right to self-determination and the right to participate in government. ${ }^{42}$ Unlike the African Commission, the Supreme Court went a step further and investigated the history of Quebec peoples' participation in government and found that Québécois have held important positions in the Federal Cabinet. It found that during the eight years prior to 1997, the Prime Minister and the Leader of the Official Opposition in the House of Commons were both Québécois. At the time of the advisory opinion, the Prime Minister, the Right Honorable Chief Justice and two members of the Supreme Court, the Chief of Staff of the Armed Forces, the Canadian Ambassador to the United States, and the Deputy Secretary General of the United Nations, were all Québécois. Based on this finding, the Supreme Court concluded that Quebec cannot plausibly succeed in a claim that it has been denied the right to meaningfully participate in government.

If the African Commission were to embark on a similar enquiry, the outcome would probably be different from Canadian experience. Many ethnic groups who seek self-rule in Africa, often have a prima facie case against their states for recognition of their right to meaningfully participate in government. Many of these ethnic groups have failed to test their claims against the African Charter because of the restricted understanding of peoples entitled to self-determination and participation in government.

In debating the definition of peoples, the Canadian Court agreed with the views of African Commissioner Umozurike when it explained in Secession of Quebec that:

It is clear that a people may include only a portion of the population of an existing state. The right to self-determination is generally used in documents that simultaneously contain references to nation and state. The juxtaposition of these terms is indicative that the reference to people does not necessarily mean the entirety of a state's population. ${ }^{43}$

It is not clear whether this language resembles the African Commission's view when it declared in Katanga that Katanga is obliged to exercise a variant of

41) Ibid at 2 .

42) Ibid.

43) Ibid, at para. 124. 
self-determination that is compatible with the sovereignty and territorial integrity of the DRC..$^{44}$ On the one hand, it is possible for one to accept that the former language resembles the latter text because the African Commission's view is that the people of Katanga may exercise self-determination in some restricted sense, thereby acknowledging that people may include individual ethnic groups. On the other hand, it is impossible for one to conclude that these texts resemble each other because if they did the African Commission's conclusion in Katanga would have been different.

The African Commission would have had to clarify the term people under the African Charter as was done in Secession of Quebec. The African Commission has scrutinized this issue in the past when it considered claims for secession from the Casamance region of Senegal. ${ }^{45}$ There, the African Commission considered arguments put forward by an ethnic group claiming secession on grounds of historical legitimacy; feelings of frustrations for being governed by outsiders; not truly sharing their cultural traditions and aspiration; and the firm conviction of being able to live better in a free and independent Casamance occupied chiefly with the well-being of its population and neighbors like Senegal. The African Commission rejected the claim for independence, partly out of fear that a claim of secession by one ethnic group would provoke other ethnic groups in Senegal to do the same. ${ }^{46}$

As demonstrated in Katanga and Casamance, it is unclear whether the African Commission may eventually expressly recognize the right to an autonomy regime for ethnic groups to exercise self-determination internally. I argue that the African Commission would more likely recognize such a right given that self-determination for distinct ethnic groups within states is understood by reference to the idea of political autonomy or self-government in the territory in which they reside and not based on secession. ${ }^{47}$ This suggests that so long as a distinct ethnic group wants to exercise its right to self-determination by way of creating an autonomy regime within its state, the African Commission would be inclined to uphold such a claim.

Moreover, it is submitted that African political leaders should keep an open mind and experiment with various forms of self-determination or power sharing arrangements such as autonomy regimes. It is my view that such experimentation could permit some countries to address or prevent certain conflicts arising from claims of self-determination. For example, the autonomy regime arrangement which began after the signing of the Comprehensive Peace Agreement

\footnotetext{
44) Katanga, supra note 13, at para. 12.

45) Report on Mission of Good Offices to Senegal of the African Commission on Human and Peoples' Rights, supra note 14 at Section V.

46) The Commission concluded that, "Given the separatist position, it is easy to demonstrate that the reasons advanced are not unique to the Casamance, but can be invoked with a certain measure of profit by other regions of Senegal." Ibid.

47) R. Murray and S. Wheately, 'Groups and the African Charter on Human and Peoples Rights' (2002) 25 Human Rights Quarterly 234.
} 
of 2005 between the Government of Sudan and the Sudan People's Liberation Movement/Sudan People's Liberation Army was a good experiment which could be replicated in other parts of Africa without necessarily leading to independence, as was the case in Southern Sudan. The lessons that should be learned from the Southern Sudan scenario is that political and power-sharing arrangements that address self-determination concerns such as the need for greater and meaningful participation in government are achievable while maintaining the sovereignty and territorial integrity of an existing state. Political arrangements such as the autonomy regimes have one considerable advantage and that is they may operate as a preventative measure to conflicts. In other words, self-determination in the form of autonomy regimes can be used to prevent rather than manage conflicts in Africa. Experience in Africa has demonstrated that it is expensive to solve or manage conflicts than prevent them, and African countries have exercised little effort towards achieving the latter. Others have described this as an effort to find African solutions to African problems.

The African Commission and other judicial bodies such as the African Court on Human and Peoples' Rights can contribute immensely to the promotion of peace, good governance and prevention of human rights violations by preferring autonomy regime and other suitable political or power-sharing arrangements through a liberal construction of the African Charter. ${ }^{48}$ To this end, Katanga was a missed opportunity for the African Commission.

\section{Conclusion}

For Africa, the Katanga decision marked a renewed commitment by the African Commission to the implementation of the right to self-determination. It demonstrated that this right is justiciable, and established a strong precedent for its judicial enforcement in states. Importantly, Katanga is the first communication before the African Commission relating directly to the right to self-determination in the post-colonial context.

By basing so much of its ruling on political considerations in the Cairo Resolution, however, the African Commission effectively undermined arguments for the recognition of a right to an autonomy regime or the classic claim of selfdetermination in the post-independence era. Many of the legal issues in Katanga will likely be raised again, either before the African Commission or the African Court of Human and Peoples' Rights, due to recent and increased claims of self-determination by groups within African states. Therefore, it is important

\footnotetext{
48) See, for example, the decision of the African Court on Human and Peoples' Rights In the Matter of African Commission on Human and Peoples' Rights v Great Socialist People's Libyan Arab Jamahiriya, Application No 004/2011 (where the African Court unanimously ordered Libya to immediately refrain from any action that would result in the loss of life or violations of the African Charter).
} 
that several of the unanswered questions raised in Katanga be resolved and allow for a process of political experimentation aimed at preventing and less on solving conflicts.

I believe Katanga would have had a much wider impact had it gone a step further rather than simply upholding outdated notions that seem to stand against political, social and economic stability in Africa. Since the African Commission recognizes that the implementation of the right to self-determination has internal as well as external dimensions, it should have clarified the scope of the internal application of this right. ${ }^{49}$ Moreover, the African Commission should have held that the term peoples under the African Charter may apply only to a portion of the population of a state, such as Africa's various ethnic and other groups. Otherwise, the African Commission's descriptions of the different forms of self-determination are meaningless if the term peoples only refer to the entire population of the state. Given that there is no definition of peoples in international law, this article recommends that the African Commission should generously construe this term.

Additionally, it seems likely from Katanga that the African Commission would entertain claims of autonomy regimes rather than full independence in light of its analysis of the different forms of self-determination and its concern over sovereignty issues. Indeed, it seems clear that the African Commission would favor an autonomy regime because of its goal of preventing conflict and the break up of states, all of which appear to be essential elements of the right to self-determination in post-independence Africa. Given this analysis, I believe that had the KPC requested autonomy as opposed to independence from the DRC, the African Commission could have reached a different conclusion. To test the utility of Katanga, future litigants should clearly indicate a request for autonomy rather than independence. In the end, self-determination remains a remedial principle that should be generously construed to encompass suitable ethnic, religious and other groups seeking autonomy within their states, and African states should view the right to self-determination as a vehicle through which conflicts could be prevented or managed.

\footnotetext{
49) See, C. J. Fromherz, 'Indigenous People' Courts: Egalitarian Juridical Pluralism, Self-Determination, and the United Nations Declaration on the Rights of Indigenous Peoples' (2008) 156 University of Pennsylvania Law Review 1341 (discussing the concepts of external and internal self-determination).
} 